\title{
Intergenerational Association of Short Maternal Stature with Stunting in Yanomami Indigenous Children from the Brazilian Amazon
}

\author{
Jesem Douglas Yamall Orellana ${ }^{1}$ (D), Giovanna Gatica-Domínguez ${ }^{2}$, Juliana dos Santos Vaz ${ }^{2,3}$ (D), \\ Paulo Augusto Ribeiro Neves ${ }^{2}$, Ana Claudia Santiago de Vasconcellos 4 , Sandra de Souza Hacon ${ }^{5}$ (D) \\ and Paulo Cesar Basta $5, * \mathbb{D}$
}

1 Leônidas e Maria Deane Institute, Oswaldo Cruz Foundation, Rua Teresina, 476, Adrianópolis, Manaus 69057-070, Brazil; jesem.orellana@gmail.com

2 Postgraduate Program in Epidemiology, Faculty of Medicine, Federal University of Pelotas, Rua Marechal Deodoro, 1160-3 Piso, Centro, Pelotas 96020-220, Brazil; giovagatica@gmail.com (G.G.-D.); juliana.vaz@gmail.com (J.d.S.V.); paugustorn@gmail.com (P.A.R.N.)

3 Faculty of Nutrition, Federal University of Pelotas, Rua Gomes Carneiro, 1, Centro, Pelotas 96010-610, Brazil

4 Laboratory of Professional Education in Health Surveillance, Joaquim Venâncio Polytechnic School of Health, Oswaldo Cruz Foundation, Av. Brasil, 4365-Manguinhos, Rio de Janeiro 21040-900, Brazil; anacsvasconcellos@gmail.com

check for updates

Citation: Orellana, J.D.Y.;

Gatica-Domínguez, G.; Vaz, J.d.S. Neves, P.A.R.; de Vasconcellos, A.C.S. de Souza Hacon, S.; Basta, P.C. Intergenerational Association of Short Maternal Stature with Stunting in Yanomami Indigenous Children from the Brazilian Amazon. Int. J. Environ. Res. Public Health 2021, 18, 9130. https://doi.org/10.3390/ ijerph18179130

Academic Editors: Rejane C. Marques, José Garrofe Dórea and Rafael Junqueira Buralli

Received: 19 July 2021

Accepted: 24 August 2021

Published: 30 August 2021

Publisher's Note: MDPI stays neutral with regard to jurisdictional claims in published maps and institutional affiliations.

Copyright: (c) 2021 by the authors. Licensee MDPI, Basel, Switzerland. This article is an open access article distributed under the terms and conditions of the Creative Commons Attribution (CC BY) license (https:// creativecommons.org/licenses/by/ $4.0 /)$
5 Samuel Pessoa Department of Endemics, National School of Public Health, Oswaldo Cruz Foundation, Rio de Janeiro 21041-210, Brazil; sandrahacon@gmail.com

* Correspondence: paulobasta@gmail.com; Tel.: +55-21-2598-2503

Abstract: To describe the factors associated to stunting in <5-year-old Yanomami Brazilian children, and to evaluate the association of short maternal stature to their offspring's stunting. A cross-sectional study carried out in three villages in the Yanomami territory. We performed a census, in which all households with children $<5$-years-old were included. The length/height-for-age $\mathrm{z}$-score $<-2$ standard deviations was used to classify the children as stunted. Short maternal height was defined as $<145 \mathrm{~cm}$ for adult women, and $<-2$ standard deviations of the height-for-age $\mathrm{z}$-score for adolescent women. We used adjusted Poisson regression models to estimate prevalence ratios (PR) along the $90 \%$ confidence interval. We evaluated 298 children. $81.2 \%$ of children suffered from stunting and $71.9 \%$ of the mothers from short stature. In the bivariate analysis, a significant association of stunting with short maternal stature, gestational malaria and child's place of birth were observed. Considering the variables of the children under five years of age, there were significant associations with age group, the child's caregiver, history of malaria, pneumonia, and malnutrition treatment. In the adjusted hierarchical model, stunting was 1.22 times greater in the offspring of women with a short stature (90\% CI: 1.07-1.38) compared to their counterparts. Brazilian Amazonian indigenous children living in a remote area displayed an alarming prevalence of stunting, and this was associated with short maternal height, reinforcing the hypothesis of intergenerational chronic malnutrition transmission in this population. In addition, children above 24 months of age, who were born in the village healthcare units and who had had previous treatment in the past for stunting presented higher rates of stunting in this study.

Keywords: poverty areas; undernutrition; indigenous populations; intergenerational relations; epidemiologic determinants

\section{Introduction}

Stunting, defined as the height-for-age deficit, not only raises the risk of mortality and incapacity in childhood [1], but is also associated with short stature in adulthood, neurocognitive development impairment, and long-term reduction in human capital [2-4]. The 2030 Agenda for sustainable development aims to eliminate all forms of malnutrition 
in children under 5 years of age (Goal 2.2) and reduce inequalities, ensuring no one is left behind (Goal 10) [5]. Unfortunately, it is expected that the Covid-19 pandemic will not only affect the discreet advancements towards eliminating all forms of malnutrition in children under 5 years of age, but it will also widen already existing socioeconomic inequalities [6,7].

In general, the indigenous peoples of Latin America have been an ethnical group disproportionately less favored [8]. Indigenous children present high prevalence of stunting when compared to non-indigenous children $[9,10]$. In Brazil, it is estimated that stunting affects approximately $6 \%$ of children under 5 years of age [11], with important regional inequalities, since stunting prevalence reaches $8.5 \%$ and $3.9 \%$ in non-indigenous children living in the North and South regions, respectively [11]. In indigenous people the situation is even worst, as stunting occurs in approximately $26 \%$ of indigenous Brazilian children, especially in the North region (nearly $41 \%$ of children experiencing stunted growth) [12]. The comparative analysis reveals deep inequalities between Brazilian macro-regions and different ethnical groups in the country.

There is evidence that short maternal height negatively influences the growth of linear offspring [13], which persists through adulthood [13-15]. Recent studies showed that growth-faltering begins during pregnancy [14]. Therefore, the need for measures to intervene and prevent the intergenerational effects (e.g., epigenetics, metabolic programming due to alterations, amongst others) associated with short maternal stature is crucial, especially during the "first 1000 days window". The interventions must seek to break the poverty cycle and the consequential intergenerational deficits in adult human capital [14].

Recognizing the worrisome nutritional situation in indigenous children, the investigation of its determinants remains an important challenge not only for sanitary authorities, but also for healthcare workers and professionals [16]. Therefore, the objective of this study was to describe the factors associated with stunting in $<5$-year-old Yanomami Brazilian children, and to evaluate the association of short maternal stature to their offspring's stunting.

\section{Materials and Methods}

\subsection{Study Area and Population}

In Brazil, the Yanomami population is comprised of nearly 28,000 individuals, distributed over 360 villages. The Yanomami Indigenous Territory (YIT) covers 9,664,975 hectares, bordering with Venezuela. This study was conducted with children under 5 years of age and their mothers, in the administrative regions Auaris and Maturacá in the Brazilian Amazon. Two villages in the Maturacá region were included in the study, namely Ariabú and Maturacá (Figure 1).

The Auaris region is located in the extreme north of the state of Roraima, one of the areas with the highest population density of the YIT (Figure 1). It is exclusively accessed by air from the state capital, Boa Vista. In turn, Maturacá is based in the Amazonas state and can be accessed by air from Boa Vista or São Gabriel da Cachoeira, Amazonas, or by land and boat from São Gabriel da Cachoeira.

\subsection{Study Design}

A cross-sectional census study was conducted between 9 and 22 December 2018 in the Auaris region and between 6 and 27 February 2019 in Ariabú and Maturacá villages. For this study, semi-structured interviews were conducted by key-informants (women/mothers or people responsible for the household) using data collection questionnaires. When key-informants did not speak Portuguese, a local translator mediated the interviews. The consent to participate was obtained through signature (or fingerprint) of the informed consent. 


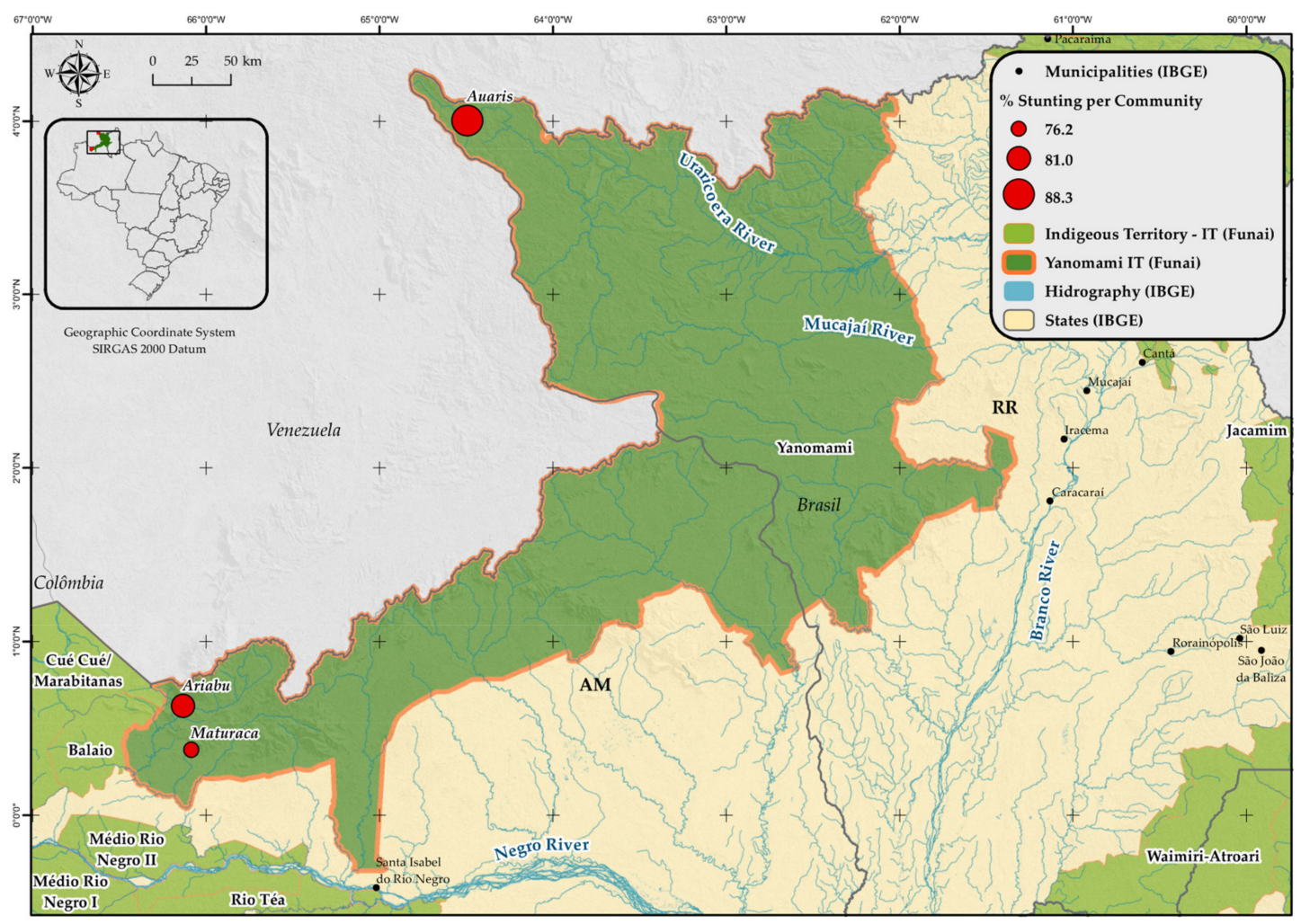

Figure 1. Studied villages in the Yanomami Indigenous Territory (YIT), according to the prevalence of stunting. Roraima and Amazonas states, Brazilian Amazon, 2018-2019.

\subsection{Maternal and Child Anthropometry}

To measure the height and weight of participants we used the following equipment: vertical anthropometer or Alturexata ${ }^{\circledR}$ stadiometer with an infantometer adaptor with a precision of $0.1 \mathrm{~cm}$ (length measure) and a Seca ${ }^{\circledR}$ portable digital scale (model 877) with maximum capacity of $150 \mathrm{~kg}$ and a precision of $0.1 \mathrm{~kg}$.

We used the WHO-Anthro ${ }^{\circledR}[17]$ and WHO-Anthro Plus ${ }^{\circledR}$ [18] programs to build the anthropometric length/height-for-age index in z-scores of children under 5 years of age and adolescent women, respectively.

We classified children as stunted and adolescent women with a short stature if they presented a length/height-for-age $z$-score less than -2 standard deviations of the median population of reference, according to the WHO Growth Charts.

Anthropometric information of six children was excluded from the analysis due to congenital malformations and implausible values of the length/height-for-age z-scores. No adolescent mother showed implausible z-score values $[17,18]$. For women older than 18 years of age, we considered a height of less than $145 \mathrm{~cm}$ as constituting a short stature [19].

\subsection{Sociodemographic, Maternal and Child Characteristics}

The following sociodemographic characteristics were considered: (i) region/village of residence (Auaris; Maturacá; Ariabú); (ii) parent knowledge (read or write) in Portuguese (yes; no); (iii) home source of income (Federal, Statal/Municipal Governments, Others or No Income); (iv) household water source for human consumption (well; river/stream); (v) waste management (thrown in the forest/river; burnt/buried); (vi) household wall-type (wood/brick; clay; straw/no wall); (vii) household density (1 to 6; 7 to $9 ; \geq 10$ people).

The maternal characteristics considered were: (i) age group (13 to $24 ; 25$ years or older); (ii) short stature (yes; no); (iii) number of antenatal consultations ( 0 to $3 ; 4$ to $6 ; 7$ 
to 9); (iv) gestational malaria history (yes; no); (v) children's place of birth (house/forest; village's healthcare units; Casa de Saúde do Índio-CASAI/Hospital).

With respect to the children, we considered the following characteristics: (i) sex (male; female); (ii) age group ( $\leq 23 ; 24$ to 59 months); (iii) child's main caregiver (mother or father, other family member); (iv) weight at birth $(<2500 \mathrm{~g} ; \geq 2500 \mathrm{~g})$; (v) previous pneumonia treatment (yes; no); (vi) previous malnutrition treatment (yes; no); (vii) previous malaria treatment (yes; no).

\subsection{Statistical Analysis}

Differences between proportion were assessed using the Pearson chi-square test. The Crude-Poisson regression, adjusted to covariables with consistent covariance matrix estimator type HC2, was used to estimate the Prevalence Ratio (PR) for stunting [20].

In the crude analysis, we selected variables with a $p$ value $<0.20$ to further adjust the analysis, using an hierarchical framework based on previous studies [21]. The conceptual hierarchical framework, established a priori, was structured into four levels and the introduction of variables in the models obeyed a hierarchical sequence. The hierarchical levels included were: 1st level (sociodemographic characteristics): region/village of residence and type of wall; 2nd level (maternal characteristics): gestational malaria and child's place of birth; 3rd level (child characteristics): age group and child main caregiver; 4th level (health history of the child): child's previous malaria treatment.

After the first selection, we used the backward method to select variables associated at $p$-values $<0.10$ in each level to the final adjust model. Pre-selected variables in each level were retained in the subsequent models, independent of their $p$-value. Additionally, the interaction between household wall-type and place of birth was tested in the final adjusted model, considering a $p$-value $<0.10$.

The villages included in the present study were based in hard-to-reach areas of the Brazilian Amazon. Due to the small sample size $(n=298)$, we adopted $p$-values of 0.10 and 0.20 as statistically significant in order to guarantee that any effects from the studied variables could be tested. However, it is worth remembering that we carried out a census in the investigated villages, and all children under 5 years of age were included in the study.

Data analysis was performed using the statistical software R, version 3.3.2 [22].

\section{Results}

The prevalence of stunting among indigenous children under 5 years of age was $81.2 \%$ (Table 1), varying greatly across villages, with the highest burden in Auaris (88.3\%) and the lowest in Ariabú (76.2\%). Considering only children older than 12 months of age, stunting prevalence was superior to $85 \%$, and in the age-group ranging from 24 to 59 months of age stunting was superior to $90 \%$, regardless of region/village. The prevalence of short maternal stature was $71.9 \%$ (mean maternal height of $143.0 \mathrm{~cm}$; standard deviation $=4.3$ ) (Table 2). Similarly to stunting in children, the highest burden of short maternal height was seen in Auaris (87.7\%) and the lowest in mothers in Ariabú (65.0\%) regions/villages.

When comparing the sociodemographic characteristics between the villages, we observed that most fathers in Auaris did not know how to read and write in Portuguese $(44.9 \%)$. Similarly, the stunting frequencies were higher among families that dispose household waste in the river or the forest $(92.4 \%)$, households with no regular income $(65.4 \%)$, and households with clay walls $(74.4 \%)$ (Table 2$)$. Furthermore, regarding maternal and perinatal variables, only $1.7 \%$ of mothers in Auaris attended between 7 and 9 antenatal visits, and only $6.4 \%$ of mothers in Auaris gave birth in a healthcare facility (hospital/CASAI).

Regarding sociodemographic variables, only household wall-type was shown to be significantly associated with stunting (Table 3 ). We found a significant association between stunting with short maternal stature, gestational malaria, and the child's place of birth. Lastly, for variables related to child health, stunting was associated with age, the child's caregiver, previous malaria, pneumonia, and previous undernutrition treatment. 
Table 1. Stunting characterization in children under 5 years of age, according to the villages of residence. Yanomami Indigenous Territory, Brazilian Amazon, 2018-2019.

\begin{tabular}{|c|c|c|c|c|c|c|c|c|c|c|c|c|}
\hline \multirow{3}{*}{ Age Group (Months) } & \multicolumn{12}{|c|}{ Stunting } \\
\hline & \multicolumn{3}{|c|}{ Auaris } & \multicolumn{3}{|c|}{ Maturacá } & \multicolumn{3}{|c|}{ Ariabú } & \multicolumn{3}{|c|}{ Total } \\
\hline & $N$ & $n$ & $\%$ & $N$ & $n$ & $\%$ & $N$ & $n$ & $\%$ & $N$ & $n$ & $\%$ \\
\hline$\leq 11$ & 12 & 7 & 58.3 & 24 & 9 & 37.5 & 25 & 7 & 28.0 & 61 & 23 & 37.7 \\
\hline 12 to 23 & 16 & 16 & 100.0 & 18 & 16 & 88.9 & 20 & 17 & 85.0 & 54 & 49 & 90.7 \\
\hline 24 to 35 & 12 & 12 & 100.0 & 22 & 22 & 100.0 & 17 & 17 & 100.0 & 51 & 51 & 100.0 \\
\hline 36 to 59 & 37 & 33 & 89.2 & 52 & 47 & 90.4 & 43 & 39 & 90.7 & 132 & 119 & 90.2 \\
\hline Total & 77 & 68 & 88.3 & 116 & 94 & 81.0 & 105 & 80 & 76.2 & 298 & 242 & 81.2 \\
\hline
\end{tabular}

$N$-total number of children in the evaluated age group; $n$-number of children with stunting.

Table 2. Sociodemographic, maternal and children under five years of age characteristics, according to the village of residence. Yanomami Indigenous Territory, Brazilian Amazon, 2018-2019.

\begin{tabular}{|c|c|c|c|c|}
\hline & \multicolumn{3}{|c|}{ Villages of Residence } & \multirow[b]{2}{*}{$p$-Value * } \\
\hline & Ariabú & Auaris & Maturacá & \\
\hline & $n(\%)$ & $n(\%)$ & $n(\%)$ & \\
\hline \multicolumn{5}{|l|}{ Sociodemographic variables } \\
\hline Read or write in Portuguese & & & & $<0.001$ \\
\hline No & $11(10.7 \%)$ & $35(44.9 \%)$ & $16(14.0 \%)$ & \\
\hline Yes & $92(89.3 \%)$ & $43(55.1 \%)$ & $98(86.0 \%)$ & \\
\hline Source of Income & & & & $<0.001$ \\
\hline Federal & $12(11.4 \%)$ & $18(23.1 \%)$ & $11(9.3 \%)$ & \\
\hline Municipal/Statal & $24(22.9 \%)$ & $4(5.1 \%)$ & $25(21.2 \%)$ & \\
\hline Other & $8(7.6 \%)$ & $5(6.4 \%)$ & $26(22.0 \%)$ & \\
\hline No income & $61(58.1 \%)$ & $51(65.4 \%)$ & $56(47.5 \%)$ & \\
\hline Drinking water source & & & & $<0.001$ \\
\hline River or stream & $82(78.1 \%)$ & $55(70.5 \%)$ & $17(14.4 \%)$ & \\
\hline Well & $23(21.9 \%)$ & $23(29.5 \%)$ & $101(86.6 \%)$ & \\
\hline Household waste destination & & & & $<0.001$ \\
\hline Burnt or buried & $38(36.2 \%)$ & $6(7.6 \%)$ & $90(76.9 \%)$ & \\
\hline Forest or river & $67(63.8 \%)$ & $73(92.4 \%)$ & $27(23.1 \%)$ & \\
\hline Household wall type & & & & $<0.001$ \\
\hline Wood/brick & $40(38.1 \%)$ & $7(9.0 \%)$ & $46(49.5 \%)$ & \\
\hline Clay & $52(49.5 \%)$ & $58(74.4 \%)$ & $61(35.7 \%)$ & \\
\hline Straw/no wall & $13(12.4 \%)$ & $13(16.6 \%)$ & $09(25.7 \%)$ & \\
\hline Household density (number of people) & & & & 0.035 \\
\hline 1 to 6 & $32(30.5 \%)$ & $18(23.7 \%)$ & $40(33.9 \%)$ & \\
\hline 7 to 9 & $27(25.7 \%)$ & $27(35.5 \%)$ & $47(39.8 \%)$ & \\
\hline 10 or more & $46(43.8 \%)$ & $31(40.8 \%)$ & $31(26.3 \%)$ & \\
\hline \multicolumn{5}{|l|}{ Maternal and perinatal variables } \\
\hline Age group (years) & & & & 0.118 \\
\hline 13.0 to 24.9 & $42(40.0 \%)$ & $20(27.7 \%)$ & $49(41.5 \%)$ & \\
\hline 25.0 or more & $63(60.0 \%)$ & $53(72.6 \%)$ & $69(58.5 \%)$ & \\
\hline Short maternal stature & & & & 0.002 \\
\hline No & $35(35.0 \%)$ & $9(12.3 \%)$ & $37(32.2 \%)$ & \\
\hline Yes & $65(65.0 \%)$ & $64(87.7 \%)$ & $78(67.8 \%)$ & \\
\hline Number of antenatal consultations & & & & $<0.001$ \\
\hline 0 to 3 & $19(21.1 \%)$ & $31(52.5 \%)$ & $22(20.2 \%)$ & \\
\hline 4 to 6 & $50(55.6 \%)$ & $27(45.8 \%)$ & $71(65.1 \%)$ & \\
\hline 7 to 9 & $21(23.3 \%)$ & $1(1.7 \%)$ & $16(14.7 \%)$ & \\
\hline Gestational malaria & & & & 0.205 \\
\hline No & $89(84.8 \%)$ & $68(93.2 \%)$ & $100(85.5 \%)$ & \\
\hline Yes & $16(15.2 \%)$ & $5(6.8 \%)$ & $17(14.5 \%)$ & \\
\hline
\end{tabular}


Table 2. Cont.

\begin{tabular}{|c|c|c|c|c|}
\hline & \multicolumn{3}{|c|}{ Villages of Residence } & \multirow[b]{2}{*}{$p$-Value * } \\
\hline & Ariabú & Auaris & Maturacá & \\
\hline & $n(\%)$ & $n(\%)$ & $n(\%)$ & \\
\hline Place of birth & & & & $<0.001$ \\
\hline Household/Forest & $57(53.8 \%)$ & $71(91.0 \%)$ & $68(59.6 \%)$ & \\
\hline Primary Healthcare Center (villages) & $27(25.5 \%)$ & $2(2.6 \%)$ & $23(20.2 \%)$ & \\
\hline Hospital/CASAI $^{1}$ & $22(20.8 \%)$ & $5(6.4 \%)$ & $23(20.2 \%)$ & \\
\hline \multicolumn{5}{|l|}{ Child's variables } \\
\hline Sex & & & & $<0.001$ \\
\hline Female & $69(65.7 \%)$ & $26(32.9 \%)$ & $81(68.6 \%)$ & \\
\hline Male & $36(34.3 \%)$ & $53(67.1 \%)$ & $37(31.4 \%)$ & \\
\hline Age group (months) & & & & 0.534 \\
\hline$\leq 23$ & $46(43.4 \%)$ & $29(36.2 \%)$ & $44(37.3 \%)$ & \\
\hline 24 to 59 & $60(56.6 \%)$ & $51(63.8 \%)$ & $74(62.7 \%)$ & \\
\hline Child's caregiver & & & & $<0.001$ \\
\hline Mother or father & $80(75.5 \%)$ & $40(50.6 \%)$ & $101(87.8 \%)$ & \\
\hline Another family member & $26(24.5 \%)$ & $39(49.4 \%)$ & $14(12.2 \%)$ & \\
\hline Low weight at birth & & & & 0.977 \\
\hline No & $93(89.4 \%)$ & $61(88.4 \%)$ & $103(88.8 \%)$ & \\
\hline Yes & $11(10.6 \%)$ & $8(11.6 \%)$ & $13(11.2 \%)$ & \\
\hline Pneumonia treatment & & & & 0.069 \\
\hline No & $70(66.7 \%)$ & $39(50.0 \%)$ & $66(56.9 \%)$ & \\
\hline Yes & $35(33.3 \%)$ & $39(50.0 \%)$ & $50(43.1 \%)$ & \\
\hline Undernutrition treatment & & & & 0.127 \\
\hline No & $93(87.7 \%)$ & $60(76.9 \%)$ & $94(79.7 \%)$ & \\
\hline Yes & $13(12.3 \%)$ & $18(23.1 \%)$ & $24(20.3 \%)$ & \\
\hline Malaria treatment & & & & 0.239 \\
\hline No & $97(91.5 \%)$ & $67(84.8 \%)$ & $108(91.5 \%)$ & \\
\hline Yes & $9(8.5 \%)$ & $12(15.2 \%)$ & $10(8.5 \%)$ & \\
\hline Stunting prevalence & & & & 0.118 \\
\hline No & $25(23.8 \%)$ & $9(11.7 \%)$ & $22(19.0 \%)$ & \\
\hline Yes & $80(76.2 \%)$ & $68(88.3 \%)$ & $94(81.0 \%)$ & \\
\hline
\end{tabular}

$n=$ number of cases observed in each variable, according to the village of residence; ${ }^{*} p$-value refers to Pearson's chi-square test; ${ }^{1} \mathrm{CASAI}$ (Casa de Saúde do Índio): Unit of support to the indigenous people who live in villages during healthcare attendance in urban centers.

Table 3. Proportion of children under five years of age with and without stunting according to sociodemographic, maternal and child variables. Yanomami Indigenous Territory, Brazilian Amazon, 2018-2019.

\begin{tabular}{|c|c|c|c|}
\hline & \multicolumn{2}{|c|}{ Stunting } & \multirow[b]{2}{*}{$p$-Value * } \\
\hline & No & Yes & \\
\hline & $n(\%)$ & $n(\%)$ & \\
\hline Sociodemographic variables & & & \\
\hline $\begin{array}{l}\text { Parent knows how to read or write in } \\
\text { Portuguese }\end{array}$ & & & 0.877 \\
\hline No & $11(20.0 \%)$ & $49(20.9 \%)$ & \\
\hline Yes & $44(80.0 \%)$ & $185(79.1 \%)$ & \\
\hline Source of Income & & & 0.305 \\
\hline Federal & $11(19.6 \%)$ & $30(12.6 \%)$ & \\
\hline Municipal/Statal & $12(21.4 \%)$ & $41(17.2 \%)$ & \\
\hline Other & $8(14.3 \%)$ & $30(12.6 \%)$ & \\
\hline No income & $25(44.6 \%)$ & $138(57.7 \%)$ & \\
\hline Drinking water source & & & 0.799 \\
\hline
\end{tabular}


Table 3. Cont.

\begin{tabular}{|c|c|c|c|}
\hline \multicolumn{4}{|c|}{ Stunting } \\
\hline & No & Yes & $p$-Value * \\
\hline & $n(\%)$ & $n(\%)$ & \\
\hline River or stream & $28(50.0 \%)$ & $124(51.9 \%)$ & \\
\hline Well & $28(50.0 \%)$ & $115(48.1 \%)$ & \\
\hline Household waste destination & & & 0.409 \\
\hline Burnt or buried & $28(50.0 \%)$ & $105(43.9 \%)$ & \\
\hline Forest or river & $28(50.0 \%)$ & $134(56.1 \%)$ & \\
\hline Household wall type & & & 0.063 \\
\hline Wood/brick & $25(44.6 \%)$ & $68(28.7 \%)$ & \\
\hline Clay & $27(48.2 \%)$ & $141(59.5 \%)$ & \\
\hline Straw/no wall & $4(7.1 \%)$ & $28(11.8 \%)$ & \\
\hline Household density (number of people) & & & 0.770 \\
\hline 1 to 6 & $17(30.4 \%)$ & $71(30.0 \%)$ & \\
\hline 7 to 9 & $17(30.4 \%)$ & $83(35.0 \%)$ & \\
\hline 10 or more & $22(39.3 \%)$ & $83(35.0 \%)$ & \\
\hline \multicolumn{4}{|l|}{ Maternal and perinatal variables } \\
\hline Age group (years) & & & 0.390 \\
\hline 13.0 to 24.9 & $17(32.1 \%)$ & $91(38.4 \%)$ & \\
\hline 25.0 or more & $36(67.9 \%)$ & $146(61.6 \%)$ & \\
\hline Short maternal stature & & & $<0.001$ \\
\hline No & $28(52.8 \%)$ & $53(23.1 \%)$ & \\
\hline Yes & $25(47.2 \%)$ & $176(76.9 \%)$ & \\
\hline Number of antenatal consultations & & & 0.797 \\
\hline 0 to 3 & $16(31.4 \%)$ & $54(26.7 \%)$ & \\
\hline 4 to 6 & $28(54.9 \%)$ & $117(57.9 \%)$ & \\
\hline 7 to 9 & $7(13.7 \%)$ & $31(15.3 \%)$ & \\
\hline Gestational malaria & & & 0.071 \\
\hline No & $52(94.5 \%)$ & $201(85.5 \%)$ & \\
\hline Yes & $3(5.5 \%)$ & $34(14.5 \%)$ & \\
\hline Place of birth & & & 0.027 \\
\hline House/Forest & $33(62.3 \%)$ & $158(66.1 \%)$ & \\
\hline Primary Healthcare Center (villages) & $5(9.4 \%)$ & $46(19.2 \%)$ & \\
\hline 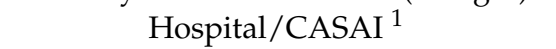 & $15(28.3 \%)$ & $35(14.6 \%)$ & \\
\hline \multicolumn{4}{|l|}{ Child variables } \\
\hline Sex & & & 0.479 \\
\hline Female & $30(54.5 \%)$ & $144(59.8 \%)$ & \\
\hline Male & $25(45.5 \%)$ & $97(40.2 \%)$ & \\
\hline Age group (months) & & & $<0.001$ \\
\hline$\leq 23$ & $43(76.8 \%)$ & $72(29.8 \%)$ & \\
\hline 24 to 59 & $13(23.2 \%)$ & $170(70.2 \%)$ & \\
\hline Child's caregiver & & & 0.089 \\
\hline Mother or father & $45(83.3 \%)$ & $170(70.8 \%)$ & \\
\hline Another family member & $9(16.7 \%)$ & $70(29.2 \%)$ & \\
\hline Low weight at birth & & & 0.779 \\
\hline No & $46(90.2 \%)$ & $207(88.8 \%)$ & \\
\hline Yes & $5(9.8 \%)$ & $26(11.2 \%)$ & \\
\hline Pneumonia treatment & & & $<0.001$ \\
\hline No & $43(78.2 \%)$ & $126(52.9 \%)$ & \\
\hline Yes & $12(21.8 \%)$ & $112(47.1 \%)$ & \\
\hline Undernutrition treatment & & & 0.002 \\
\hline No & $54(96.4 \%)$ & $189(78.8 \%)$ & \\
\hline Yes & $2(3.6 \%)$ & $51(21.2 \%)$ & \\
\hline Malaria treatment & & & 0.072 \\
\hline No & $54(96.4 \%)$ & $213(88.4 \%)$ & \\
\hline Yes & $2(3.6 \%)$ & $28(11.6 \%)$ & \\
\hline
\end{tabular}

$n=$ number of cases observed; * $p$-value refers to Poisson regression; ${ }^{1}$ Casa de Saúde do Índio: Unit of support to the indigenous people who live in villages during healthcare attendance in urban centers. 
In the hierarchical multiple regression analysis, which included the interactive term between household wall-type and child's place of birth, the final model indicated a stunting risk of $22 \%(7-38 \%)$ higher in children whose mothers with a short stature, compared to those with normal stature (Table 4).

Table 4. Crude and adjusted hierarchical models of the association between stunting in Yanomami children under five years old and short maternal height. Yanomami Indigenous Territory, Brazilian Amazon, 2018-2019.

\begin{tabular}{|c|c|c|c|c|c|}
\hline Level & Variable & $\begin{array}{l}\text { Crude PR } \\
\text { (CI 80\%) }\end{array}$ & $p$-Value & $\begin{array}{l}\text { Adjusted PR } \\
\text { (CI 90\%) }\end{array}$ & $p$-Value \\
\hline \multirow{8}{*}{1} & Region/village of residence & & & & \\
\hline & Ariabú & 1 & & 1 & \\
\hline & Auaris & $1.07(1.06-1.27)$ & 0.032 & $1.09(0.97-1.22)$ & 0.222 \\
\hline & Maturacá & $1.07(0.97-1.16)$ & 0.385 & $1.04(0.93-1.17)$ & 0.563 \\
\hline & Household wall type & & & & \\
\hline & Wood/brick & 1 & & 1 & \\
\hline & Clay & $1.15(1.05-1.26)$ & 0.055 & $1.13(1.01-1.26)$ & 0.088 \\
\hline & Straw/no wall & $1.20(1.06-1.35)$ & 0.053 & $1.19(1.01-1.40)$ & 0.082 \\
\hline \multirow{7}{*}{2} & Gestational malaria & & & & \\
\hline & No & 1 & & 1 & \\
\hline & Yes & $1.06(1.07-1.25)$ & 0.014 & $1.12(1.01-1.25)$ & $0.070^{\mathrm{a}}$ \\
\hline & Place of birth & & & & \\
\hline & Hospital/Casai & 1 & & 1 & \\
\hline & Forest & $1.10(1.04-1.34)$ & 0.092 & $1.17(0.99-1.38)$ & $0.118^{b}$ \\
\hline & $\begin{array}{l}\text { Primary Healthcare Center } \\
\text { (in the villages) }\end{array}$ & $1.11(1.13-1.47)$ & 0.015 & $1.26(1.05-1.51)$ & $0.041^{b}$ \\
\hline \multirow{6}{*}{3} & Age group (months) & & & & \\
\hline & $\leq 23$ & 1 & & 1 & \\
\hline & 24 to 59 & $1.08(1.35-1.63)$ & 0.001 & $1.48(1.30-1.67)$ & $0.001^{\mathrm{c}}$ \\
\hline & Child's caregiver & & & & \\
\hline & Mother or father & 1 & & 1 & \\
\hline & Other family member & $1.06(1.05-1.20)$ & 0.034 & $1.10(1.01-1.20)$ & $0.080^{\mathrm{d}}$ \\
\hline \multirow{3}{*}{4} & Malaria treatment & & & & \\
\hline & No & 1 & & 1 & \\
\hline & Yes & $1.06(1.09-1.26)$ & 0.007 & $1.05(0.95-1.17)$ & $0.412^{\mathrm{e}}$ \\
\hline & Child stunting (outcome) & & & & \\
\hline & No & 1 & & 1 & \\
\hline & Yes & $1.34(1.20-1.49)$ & 0.001 & $1.22(1.07-1.38)$ & $0.012^{f}$ \\
\hline
\end{tabular}

PR = Prevalence Ratio; ${ }^{a}$ Adjusted by wall-type. ${ }^{b}$ Adjusted by wall-type and gestational malaria. ${ }^{c}$ Adjusted by wall-type, gestational malaria and place of birth. ${ }^{\mathrm{d}}$ Adjusted by wall-type, gestational malaria, place of birth and age group. ${ }^{\mathrm{e}}$ Adjusted by wall-type, gestational malaria, place of birth, age group and child's caregiver. ${ }^{\mathrm{f}}$ Adjusted by wall-type, gestational malaria, place of birth, age group and child's caregiver to the interaction between wall-type and place of birth.

\section{Discussion}

We described an alarming prevalence of stunting among Brazilian indigenous children living in the Amazon. Additionally, we found a significant association between short maternal stature and stunting in the offspring. Such findings reinforce the hypothesis of intergenerational transmission of stunting in Yanomami indigenous people, highlighting the precarity of health and nutrition conditions in these settings.

Stunting prevalence varies markedly across regions of the world. Recent evidence suggests that stunting occurs in $39.0 \%$ and $55.0 \%$ of African and Asian children under five, respectively $[6,23]$. In Brazil, a nationwide survey showed that $40.8 \%$ of indigenous children under five years of age, living in the North region, suffered from stunting [12]. In contrast, stunting prevalence of $6.3 \%$ and $5.7 \%$ were reported in the same period for nonindigenous boys and girls under 5 years of age in the same area, respectively [11], revealing huge inequalities in the nutritional status of indigenous children in Brazil. Despite the chronic patterns of stunting among indigenous people globally, a prevalence of stunting 
above $80 \%$ have only been reported among Yanomami children, highlighting the critical nutritional status of this group [24,25].

Scientific research on the determinants of the nutritional status in indigenous children under five years of age can improve public policies and reduce social inequalities in health, fostering social protection mechanisms. At the same time, the association between short maternal stature and stunting in our study showed not only an intergenerational effect but reinforces previous findings of the high burden of stunting in Yanomami children, as well as the need for interventions aimed at breaking down the cycle of sickness and death that remain for decades [24-30].

The critical scenario revealed in this study confirms that the high rates of stunting persist for a long time in the Yanomami Indigenous territory as a result of not only a permanent state of food insecurity but also due to structural racism historically imposed by the Government. In contrast with the goals of the 2030 Agenda for sustainable development [5], which aim to eliminate all forms of malnutrition in children under five years of age and reduce inequalities, leaving no one behind, and the United Nations Declaration on the Rights of Indigenous Peoples (UNDRIP) [31,32], the Brazilian Government has not fulfilled its duty.

Throughout history, the indigenous people have been marginalized, discriminated against, and exploited by Western society. In turn, the Government has not implemented inclusive and sustainable public policies to reduce poverty and starvation and promote reparation for the violations suffered by these peoples. In addition, the Government continues to deny them access to essential public services, such as health, sanitation, education, employment, and income, as well as the rights to self-determination and the control over natural resources existing on their traditional territories. Moreover, in the last couple of years, several bills have been presented to the parliament in order to reduce rights assured in the Brazilian Federal Constitution.

Therefore, we consider that the path to sovereignty should be built in another way, putting on the indigenous people at the center of the debate, valorizing their culture and their traditional knowledge, in order to attain a fairer and equitable society, where no child, no citizen and no nations will be left behind.

A recent analysis regarding ethnic inequalities in the prevalence of stunting in children under 5 years of age in 13 Latin American countries showed a highly unfavorable situation for indigenous populations. The polled prevalence ratio of stunting for all countries was 1.34 (CI 95\% 1.28 to 1.39) for indigenous children compared to non-indigenous children, even after adjustments were made to household wealth and place of residence [9]. Furthermore, another study conducted in Latin American countries showed a low coverage of healthcare services for indigenous women and children when compared to non-indigenous people, independent of wealth or place of residence [33]. Although these studies did not capture the specific space-temporal contextual particularities, they reinforce social inequality and precarious access to healthcare and sanitary services by indigenous people, even though such items are considered part of universal rights [32,33]. In Brazil, indigenous people are a minority, and they represent less than $0.5 \%$ of the country's population, which makes the adoption and implementation of a broad intercultural healthcare model crucial [34].

The well-known intergenerational transmission of poverty and some critical prenatal determinants play a significant role in the high burden of stunting in many parts of the world. The more precarious the living conditions, the worse the malnutrition indicators in children, notably the stunting cases [35]. This phenomenon is consistent with the social determinants of the child malnutrition model developed by UNICEF [36], that states that the precarious conditions of health and maternal diet, before conception and during pregnancy, as well as a persistent exposure to a poor diet, considering quantity and quality of the food (i.e., food with low energy, protein, and micronutrients content), in addition, recurrent infections of infancy are each among the leading causes of stunting. On the other 
hand, other causes of stunting include food insecurity, inadequate feeding practices, an unhealthy domestic environment, inadequate healthcare service access, and poverty [36].

Food insecurity leads to the reduction in quantity and quality of consumed foods, as well as changing eating habits, due to lack of money or the absence of other material resources. This combination of factors acting together negatively affects the nutritional status, health and welfare of families [36]. There is evidence that indigenous children between 6 and 23 months of age in Latin American countries receive maternal milk for a longer period of time, however, the complementary foods available for these children are low in quality. Therefore, the availability of maternal milk for a longer period of time does not seem sufficient to meet the nutritional needs of the children in this age group. Consequently, these children are more susceptible to catch-up delays in growth [9].

It is important to point out that, historically, indigenous people have been exposed to high loads of infectious and parasitic diseases, both in terms of frequency and seriousness of the reported clinical conditions $[37,38]$. In this sense, parasitic infestation, gastrointestinal infections, and enteric environmental disfunctions are especially important due to negative effects in nutrient digestion and absorption, threatening not only the growth potential, but also raising the risk of death in indigenous children [39-41]. The precarious sanitary conditions in the indigenous villages in Latin America [42], as well as those observed in the studied Yanomami children-including the limited access to potable drinking water and inadequate household waste destination-help to understand not only the elevated and permanent exposure of these children to infectious and parasitic diseases [30], but the severity of the nutritional situation. The precarious nutritional status of the Yanomami children living in Brazil and Venezuela [24-29] has been systematically denounced for at least three decades.

One of the long-term consequences of stunting in childhood is the short stature in adulthood [43]. Mothers with a short stature in adulthood can give birth to tiny babies due to an insufficient supply of nutrients or due to an unfavorable intrauterine environmentdue to lack of food-for adequate fetal growth [44]. Our findings reinforce another record from Orellana et al. [24] that shows an association between short maternal stature and severe stunting in Yanomami children under five years of age who reside in other regions of the YIT in Brazil. In the same study, the authors also revealed a stunting prevalence of $83.8 \%$, and that children of mothers with height $<145 \mathrm{~cm}$ presented higher prevalence of stunting (PR: 2.1; CI 95\%: 1.2-3.6) compared to children of mothers with stature $\geq 145 \mathrm{~cm}$.

In turn, a study using data from birth cohorts carried out in five low- or middleincome countries (Brazil, Guatemala, India, Philippines, and South Africa) showed that mothers with a stature shorter than $150.1 \mathrm{~cm}$ presented a 3.2 times higher probability of having children with stunting at 2 years of age (CI 95\%: 2.8-3.6) and 4.7 times higher in the adulthood (CI 95\%: 4.1-5.4), when compared to mothers with a higher stature [13].

Other potential threats help explain the precarious nutritional conditions of the Yanomami Brazilian children, such as the invasions of the traditional territories by illegal miners, loggers, grabbing, and other criminals searching of wealth in the Amazon Forest $[45,46]$. All factors previously mentioned can simultaneously increase the risks of food insecurity and the maintenance of stunting in children under five years of age and all family members living in the region.

Despite the illustrative findings of this investigation, consistent with the specialized literature, it is important to consider the limitations. It was not possible to evaluate children who were receiving healthcare treatments outside of the villages at the time of our visits. On the one hand, this could have contributed to underestimation of stunting prevalence in our study. On the other hand, the reduced number of villages included in this study does not represent the nutritional status of all the children who live in the YIT, thus requiring caution in the generalizations of the results. Although all of the house visits were conducted with a local translator, the information bias cannot be disregarded, as well as memory bias, especially in questions related to healthcare services access and former sickness in older children. 
Aside the aforementioned limitations, it is worth highlighting that although the number of Yanomami children evaluated $(n=298)$ could be considered small, it was expressive since these children live in regions with difficult access and that, in certain circumstances, these children can pass months without regular visits by healthcare teams. Under the methodological point of view, the exposure and the outcome evaluated in this study were measured following quality recommendations standards by WHO. Despite the cross-sectional nature of our data, we can say that the reverse causality phenomenon did not affect our association estimates, since the short maternal stature exposure was already defined before pregnancy and childbirth, which eliminates the exposure-outcome temporality dilemma in our data. Finally, even without excluding the possibility of residual confusion, we adopted robust data analysis methods by a hierarchical approach, using a measure of appropriate association to sectional studies.

\section{Conclusions}

The high prevalence of stunting recorded in children under 5 years of age in the Yanomami Indigenous territory, especially those living in the Auaris region, reveals an alarming and unprecedented situation of health neglect. Therefore, it is essential to remember that Article 21 of the United Nations Declaration on the Rights of Indigenous Peoples assures that: "Indigenous peoples have the right, without discrimination, to the improvement of their economic and social conditions, including, among other things, in the areas of education, employment, vocational training and retraining, housing, sanitation, health and social security" [33].

In conclusion, even if the birth of many generations is necessary to eliminate the effects of intergenerational short stature, it is vital to understand that specific, broad, and inclusive nutritional interventions and programs are essential to prevent stunting in an ethnic and culturally differentiated context, especially if they are addressed in the first 1000 days of a child's life. This period is considered a unique window of opportunity, especially in indigenous children, seriously affected by stunting. Therefore, effective multisectoral measures must be implemented to eradicate stunting in the Yanomami Territory.

Finally, we consider it equally essential to create sustainable projects by the Federal Government in close collaboration with non-governmental organizations and indigenous associations. These projects must propose strategies to assure regular income generation with the participation of local society in managing the resources, assuring self-identification patterns, cultural valorizing, respect to ancient knowledge, and traditional foods. The ultimate goal should be to reach food sovereignty and social inclusion, guaranteeing basic water supply services, sanitation in villages, and regular access to health services.

Author Contributions: Conceptualization, J.D.Y.O. and P.C.B.; methodology, J.D.Y.O.; A.C.S.d.V.; S.d.S.H. and P.C.B.; formal analysis, J.D.Y.O.; G.G.-D.; J.d.S.V.; P.A.R.N. and P.C.B.; investigation, J.D.Y.O.; A.C.S.d.V. and P.C.B.; resources, J.D.Y.O. and P.C.B.; writing—original draft preparation, J.D.Y.O.; G.G.-D.; J.d.S.V. and P.A.R.N.; writing-review and editing, J.D.Y.O. and P.C.B.; project administration, J.D.Y.O. and P.C.B.; funding acquisition, P.C.B. All authors have read and agreed to the published version of the manuscript.

Funding: This research was funded by the United Nations International Children's Emergency Fund (UNICEF), contract number 43246507/2018.

Institutional Review Board Statement: The study was conducted in accordance with the guidelines of the Declaration of Helsinki and the study protocol was submitted and approved by the Research Ethics Committee of the National School of Public Health at Fiocruz (REC/ENSP) and the Brazilian National Research Ethics Commission of the National Health Council (CONEP/CNS) (CAAE: 91612218.8.0000.5240, Opinion number 2.896.403). In addition, the research team requested authorization to the Fundação Nacional do Indio (FUNAI) for entrance in the Yanomami Indigenous Territory and a previous consultation of the studied communities was conducted before the fieldwork. The data collection instruments were applied only after expressed consent in the informed consent forms. 
Informed Consent Statement: Informed consent was obtained from all subjects involved in the study. Written informed consent has been obtained from the mothers and/or caregivers of the children to publish this paper.

Data Availability Statement: Data sharing not applicable.

Acknowledgments: Through chiefs Davi Kopenawa Yanomami, Francisco Xavier da Silva, and Floriza da Cruz Pinto which represented of Hutukara Yanomami Association (HAY), Association of Yanomami Women (Kumirãyõma), and Yanomami of Cauaburis River and Tributaries Association (AYRCA) at the fielwork, we thank the Yanomami indigenous people for the trust placed in our team and the support in carrying out the research. We would thank Cristina Albuquerque and the technical team from UNICEF Brazil for funding this research. We thank the Yanomami Indigenous Special Sanitary District (DSEI-Y) coordination, which spared no effort to support us in all stages of the fieldwork. On behalf of all teams that work for DSEI-Y, we thank the nurses Eliane Sanches Henriques and Geovanny Ribeiro Carvalho. We also thank Anderson Vasconcelos, Clarisse do Carmo Jabur and Túlio Caio Binotti from National Indian Foundation (FUNAI) to the logistic and legal support. Finally, we thank Daniel de Oliveira d'El Rei Pinto, who made the study area map. We appreciate the Joênia Wapichana Federal Deputy for her support for publication fee costs through the parliamentary amendment number 41510004.

Conflicts of Interest: The authors declare no conflict of interest. The funders had no role in the design of the study; in the collection, analyses, or interpretation of data; in the writing of the manuscript, or in the decision to publish the results.

\section{References}

1. World Health Organization (WHO). WHO Child Growth Standards: Length/Height-for-Age, Weight-for-Age, Weight-for-Length, Weight-for-Height and Body Mass Index-for-Age; Methods and Development; WHO (Nonserial Publication); WHO: Geneva, Switzerland, 2006.

2. Black, R.E.; Allen, L.H.; Bhutta, Z.A.; Caulfield, L.E.; De Onis, M.; Ezzati, M.; Mathers, C.; Rivera, J.; Maternal and Child Undernutrition Study Group. Maternal and child undernutrition: Global and regional exposures and health consequences. Lancet 2008, 371, 243-260. [CrossRef]

3. Ozaltin, E.; Hill, K.; Subramanian, S.V. Association of maternal stature with offspring mortality, underweight, and stunting in low- to middle-income countries. JAMA 2010, 303, 1507-1516. [CrossRef] [PubMed]

4. Stein, A.D.; Wang, M.; Martorell, R.; Norris, S.A.; Adair, L.S.; Bas, I.; Sachdev, H.S.; Bhargava, S.K.; Fall, C.H.D.; Gigante, D.; et al. Growth patterns in early childhood and final attained stature: Data from five birth cohorts from low- and middle-income countries. Am. J. Hum. Biol. 2010, 22, 353-359. [CrossRef] [PubMed]

5. United Nations (UN). Transforming Our World: The 2030 Agenda for Sustainable Development; Division for Sustainable Development Goals: New York, NY, USA, 2021.

6. UNICEF; WHO; World Bank Group. Levels and Trends in Child. Malnutrition; UNICEF-WHO-World Bank Group Joint Child Malnutrition Estimates: Key Findings of the 2019 Edition; UNICEF: New York, NY, USA; WHO: Geneva, Switzerland; World Bank Group: Washington, DC, USA, 2019.

7. Victora, C.G.; Christian, P.; Vidaletti, L.P.; Gatica-Domínguez, G.; Menon, P.; Black, R.E. Revisiting maternal and child undernutrition in low-income and middle-income countries: Variable progress towards an unfinished agenda. Lancet 2021, 397, 1388-1399. [CrossRef]

8. World Bank Group. Indigenous Latin America in the Twenty-First Century: The First Decade. World Bank. (C) World Bank. 2015. Available online: https:/ / openknowledge.worldbank.org/handle/10986/23751 (accessed on 23 June 2021).

9. Gatica-Domínguez, G.; Victora, C.; Barros, A.J. Ethnic inequalities and trends in stunting prevalence among Guatemalan children: An analysis using national health surveys 1995-2014. Int. J. Equity Health 2019, 18, 1-11. [CrossRef] [PubMed]

10. Amarante, V.; Figueroa, N.; Ullman, H. Inequalities in the reduction of child stunting over time in Latin America: Evidence from the DHS 2000-2010. Oxf. Dev. Stud. 2018, 46, 519-535. [CrossRef]

11. Instituto Brasileiro de Geografia e Estatística (IBGE). Pesquisa de Orçamentos Familiares (POF): Antropometria e Estado Nutricional de Crianças, Adolescentes e Adultos no Brasil; IBGE: Rio de Janeiro, Brazil, 2010.

12. Horta, B.L.; Santos, R.V.; Welch, J.R.; Cardoso, A.M.; dos Santos, J.V.; Assis, A.M.; Lira, P.C.; Coimbra, C.E., Jr. Nutritional status of indigenous children: Findings from the First National Survey of Indigenous People's Health and Nutrition in Brazil. Int. J. Equity Health 2013, 12, 23. [CrossRef]

13. Addo, O.Y.; Stein, A.D.; Fall, C.H.; Gigante, D.P.; Guntupalli, A.M.; Horta, B.L.; Kuzawa, C.W.; Lee, N.; Norris, S.A.; Consortium on Health Orientated Research in Transitional Societies (COHORTS) Group; et al. Maternal height and child growth patterns. J. Pediatrics 2013, 163, 549-554. [CrossRef]

14. De Onis, M.; Branca, F. Childhood stunting: A global perspective. Matern. Child. Nutr. 2016, 12, 12-26. [CrossRef] 
15. Prendergast, A.J.; Humphrey, J.H. The stunting syndrome in developing countries. Paediatr. Int. Child. Health 2014, 34, 250-265. [CrossRef]

16. Ferreira, A.A.; Welch, J.R.; Cunha, G.M.; Júnior, C.C.E.A. Physical growth curves of indigenous Xavante children in Central Brazil: Results from a longitudinal study (2009-2012). Ann. Hum. Biol. 2016, 43, 293-303. [CrossRef]

17. WHO. WHO-Anthro for Personal Computers, Version 3.2.2, 2011: Software for Assessing Growth and Development of the World's Children; WHO: Geneva, Switzerland, 2010.

18. WHO. WHO-AnthroPlus for Personal Computers, Manual: Software for Assessing Growth of the World's Children and Adolescents; WHO: Geneva, Switzerland, 2009.

19. Nestel, P.; Rutstein, S. Defining nutritional status of women in developing countries. Public Health Nutr. 2002, 5, 1727. [CrossRef] [PubMed]

20. Cribari Neto, F.; Ferrari, S.L.; Cordeiro, G.M. Improved heteroscedasticity consistent covariance matrix estimators. Biometrika 2000, 87, 907-918. [CrossRef]

21. Victora, C.G.; Huttly, S.R.; Fuchs, S.C.; Olinto, M. The role of conceptual frameworks in epidemiological analysis: A hierarchical approach. Int. J. Epidemiol. 1997, 26, 224-227. [CrossRef]

22. The R Foundation. The R Project for Statistical Computing [Internet]; The R Foundation: Vienna, Austria, 2021; Available online: http:/ / www.r-project.org (accessed on 31 May 2021).

23. Manjong, F.T.; Verla, V.S.; Egbe, T.O.; Nsagha, D.S. Undernutrition among under-five indigenous Mbororo children in the Foumban and Galim health districts of Cameroon: A cross-sectional study. Pan. Afr. Med. J. 2021, 38. [CrossRef]

24. Orellana, J.D.Y.; Marrero, L.; Alves, C.L.M.; Ruiz, C.M.V.; Hacon, S.S.; Oliveira, M.W.; Basta, P.C. Associação de baixa estatura severa em crianças indígenas Yanomami com baixa estatura materna: Indícios de transmissão intergeracional. Ciência Saúde Coletiva 2019, 24, 1875-1883. [CrossRef]

25. Pantoja, L.N.; Orellana, J.D.Y.; Leite, M.S.; Basta, P.C. Cobertura do Sistema de Vigilância Alimentar e Nutricional Indígena (SISVAN-I) e prevalência de desvios nutricionais em crianças Yanomami menores de 60 meses, Amazônia, Brasil. Rev. Bras. Saúde Matern. Infant. 2014, 14, 53-63. [CrossRef]

26. Verhagen, L.M.; Incani, R.N.; Franco, C.R.; Ugarte, A.; Cadenas, Y.; Sierra Ruiz, C.I.; Hermans, P.W.; Hoek, D.; Campos Ponce, M.; de Waard, J.H.; et al. High malnutrition rate in Venezuelan Yanomami compared to Warao Amerindians and Creoles: Significant associations with intestinal parasites and anemia. PLoS ONE 2013, 8, e77581. [CrossRef]

27. Hidalgo, G.; Marini, E.; Sanchez, W.; Contreras, M.; Estrada, I.; Comandini, O.; Buffa, R.; Magris, M.; Dominguez-Bello, M.G. The nutrition transition in the Venezuelan Amazonia: Increased overweight and obesity with transculturation. Am. J. Hum. Biol. 2014, 26, 710-712. [CrossRef]

28. Pithan, O.A.; Confalonieri, U.E.; Morgado, A.F. A situação de saúde dos índios Yanomámi: Diagnóstico a partir da Casa do Índio de Boa Vista, Roraima, 1987-1989. Cad. Saúde Pública 1991, 7, 563-580. [CrossRef]

29. Grenfell, P.; Fanello, C.I.; Magris, M.; Goncalves, J.; Metzger, W.G.; Vivas-Martínez, S.; Vivas, L.; Curtis, C. Anaemia and malaria in Yanomami communities with differing access to healthcare. Trans. R. Soc. Trop. Med. Hyg. 2008, 102, 645652. [CrossRef] [PubMed]

30. Caldart, R.V.; Marrero, L.; Basta, P.C.; Orellana, J.D.Y. Fatores associados à pneumonia em crianças Yanomami internadas por condições sensíveis à atenção primária na região norte do Brasil. Ciência Saúde Coletiva 2016, 21, 1597-1606. [CrossRef] [PubMed]

31. International Labour Organization (ILO), Indigenous and Tribal Peoples Convention, C169, 27 June 1989, C169. Available online: https: / / www.refworld.org/docid/3ddb6d514.html (accessed on 7 June 2021).

32. UN. UN Document A/61/L.67 12 September 2007: The United Nations Declaration on the Rights of Indigenous Peoples, Adopted by the UN General Assembly on 13 September 2007; UN: New York, NY, USA, 2007.

33. Mesenburg, M.A.; Restrepo-Mendez, M.C.; Amigo, H.; Balandrán, A.D.; Barbosa-Verdun, M.A.; Caicedo-Velásquez, B.; CarvajalAguirre, L.; Coimbra, C.E., Jr.; Ferreira, L.Z.; del Pilar Flores-Quispe, M.; et al. Ethnic group inequalities in coverage with reproductive, maternal and child health interventions: Cross-sectional analyses of national surveys in 16 Latin American and Caribbean countries. Lancet Glob. Health 2018, 6, e902-e913. [CrossRef]

34. Mignone, J.; Bartlett, J.; O'Neil, J.; Orchard, T. Best practices in intercultural health: Five case studies in Latin America. J. Ethnobiol. Ethnomedicine 2007, 3, 31. [CrossRef]

35. Svefors, P.; Sysoev, O.; Ekstrom, E.C.; Persson, L.A.; Arifeen, S.E.; Naved, R.T.; Rahman, A.; Khan, A.I.; Selling, K. Relative importance of prenatal and postnatal determinants of stunting: Data mining approaches to the MINIMat cohort, Bangladesh. BMJ 2019, 9, e025154. [CrossRef]

36. United Nations Children's Fund (UNICEF). Improving Child. Nutrition: The Achievable Imperative for Global Progress; UNICEF: New York, NY, USA, 2013.

37. Anderson, I.; Robson, B.; Connolly, M.; Al-Yaman, F.; Bjertness, E.; King, A.; Tynan, M.; Madden, R.; Bang, A.; Coimbra, C.E., Jr.; et al. Indigenous and tribal peoples' health (The Lancet-Lowitja Institute Global Collaboration): A population study. Lancet 2016, 388, 131-157. [CrossRef]

38. Basnayake, T.L.; Morgan, L.C.; Chang, A.B. The global burden of respiratory infections in indigenous children and adults: A review. Respirology 2017, 22, 1518-1528. [CrossRef]

39. Valeggia, C.R.; Snodgrass, J.J. Health of indigenous peoples. Annu. Rev. Anthropol. 2015, 44, 117-135. [CrossRef]

40. Gracey, M.; King, M. Indigenous health part 1: Determinants and disease patterns. Lancet 2009, 374, 65-75. [CrossRef] 
41. Tickell, K.D.; Atlas, H.E.; Walson, J.L. Environmental enteric dysfunction: A review of potential mechanisms, consequences and management strategies. BMC Med. 2019, 17, 1-9. [CrossRef]

42. Jiménez, A.; Cortobius, M.; Kjellén, M. Water, sanitation and hygiene and indigenous peoples: A review of the literature. Water Int. 2014, 39, 277-293. [CrossRef]

43. FAO; FIDA; OPS; WFP; UNICEF. Panorama de la Seguridad Alimentaria y Nutrición en América Latina y el Caribe 2020; FAO: Rome, Italy; OPS: Washington, DC, USA; WFP: Rome, Italy; UNICEF: New York, NY, USA, 2020; Available online: http: / / www.fao.org/documents/card/en/c/cb2242es / (accessed on 30 June 2021). [CrossRef]

44. Martorell, R.; Zongrone, A. Intergenerational influences on child growth and undernutrition. Paediatr. Perinat. Epidemiol. 2012, 26, 302-314. [CrossRef] [PubMed]

45. The Guardian. Brazilian wildcat miners attack police and burn indigenous homes in Amazon [Internet]. 2021. Available online: https: / / www.theguardian.com/world/2021/may/28/brazil-wildcat-miners-police-indigenous-amazon (accessed on 31 May 2021).

46. Fellows, M.; Paye, V.; Alencar, A.; Nicácio, M.; Castro, I.; Coelho, M.E.; Silva, C.V.J.; Bandeira, M.; Lourival, R.; Basta, P.C. Under-Reporting of COVID-19 Cases Among Indigenous Peoples in Brazil: A New Expression of Old Inequalities. Front. Psychiatry 2021, 12, 638359. [CrossRef] [PubMed] 